\title{
Tissue Engineering Strategies for Improving Beta Cell Transplantation Outcome
}

\author{
Shadab Abadpour ${ }^{1,2,3}$ (D) Chencheng Wang ${ }^{2,3} \cdot$ Essi M. Niemi ${ }^{2,3,4} \cdot$ Hanne Scholz ${ }^{1,2,3}$ (1)
}

Accepted: 28 May 2021 / Published online: 25 June 2021

(C) The Author(s) 2021

\begin{abstract}
Purpose of Review Beta cell replacement therapy as a form of islet transplantation is a promising alternative therapy with the possibility to make selected patients with type 1 diabetes (T1D) insulin independent. However, this technique faces challenges such as extensive activation of the host immune system post-transplantation, lifelong need for immunosuppression, and the scarcity of islet donor pancreas. Advancement in tissue engineering strategies can improve these challenges and allow for a more widespread application of this therapy. This review will discuss the recent development and clinical translation of tissue engineering strategies in beta cell replacement therapy.

Recent Findings Tissue engineering offers innovative solutions for producing unlimited glucose responsive cells and fabrication of appropriate devices/scaffolds for transplantation applications. Generation of pancreatic organoids with supporting cells in biocompatible biomaterials is a powerful technique to improve the function of insulin-producing cell clusters. Fabrication of physical barriers such as encapsulation strategies can protect the cells from the host immune system and allow for graft retrieval, although this strategy still faces major challenges to fully restore physiological glucose regulation.

Summary The three main components of tissue engineering strategies including the generation of stem cell-derived insulinproducing cells and organoids and the possibilities for therapeutic delivery of cell-seeded devices to extra-hepatic sites need to come together in order to provide safe and functional insulin-producing devices for clinical beta cell replacement therapy.
\end{abstract}

Keywords Tissue engineering $\cdot$ Organoids $\cdot$ Encapsulation $\cdot$ Stem cell-derived insulin-producing cells

This article is part of the Topical Collection on Tissue Engineering and Regeneration

Hanne Scholz

Hanne.scholz@medisin.uio.no

Shadab Abadpour

Shadab.abadpour@rr-research.no

Chencheng Wang

chencheng.wang@medisin.uio.no

Essi M. Niemi

Essi.Niemi@rr-research.no

1 Department of Transplant Medicine, Oslo University Hospital, Post Box 4950, Nydalen, N-0424 Oslo, Norway

2 Institute for Surgical Research, Oslo University Hospital, Post Box 4950, Nydalen, N-0424 Oslo, Norway

3 Hybrid Technology Hub-Centre of Excellence, Institute of Basic Medical Sciences, University of Oslo, Oslo, Norway

4 Department of Vascular Surgery, Aker Hospital, Oslo University Hospital, Post Box 4950, Nydalen, N-0424 Oslo, Norway

\section{Introduction}

Patients suffering from severe T1D can be offered to receive beta cell replacement therapy, either as a whole pancreas or as islet transplantation. In the latter, the pancreatic islets are first isolated from a diseased donor, followed by an intraportal hepatic infusion [1]. This treatment is safe and effective and offers significant benefits to T1D patients including improvement in hemoglobin A1c (HbAlc) and reduction in their daily insulin need. The patients can suffer less from diabetes complications and are at lower risk of becoming hyperglycemic, which improve the quality of life and in some cases help to achieve full insulin independency [2,3]. The first successful clinical human islet transplantation, known as Edmonton-like protocol, emphasizes on the use of steroid-free immunosuppressive regimen with insulin and anti-oxidant therapy in combination with a larger transplanted islet mass $(>11,000$ islet equivalent (IEQ)/kg body weight) $[4,5]$. This success was a significant milestone in islet transplantation that led to stimulate the opening of several centers around the world and 
a significant increase in the number of islet transplantations [6]. The progress in the field has led to a transition of islet transplantation from being an experimental therapy to a routine clinical procedure; however, the widespread application of the procedure is not yet possible due to the shortage of suitable donor pancreases and the need for broad immunosuppression. In addition, the long-term restoration of beta cell function and normalization of blood glucose have not yet been achieved. This is partly due to the early islet graft damage post-transplantation resulting from the activation of the instant blood inflammatory reaction (IBMIR), in which the newly transplanted islets are exposed to the blood components of the recipient $[1,7]$. Thus, to improve the outcome of islet transplantation procedure and broaden the application to more patients, there is an urgent need for a renewable source of beta cells, effective strategies to avoid early graft loss, and induction of allo-immune tolerance.

Tissue engineering strategies offer tools to differentiate functional insulin-producing cells from pluripotent stem cells or progenitor cells [8]. These cells must be able to mimic the native islets and maintain specific phenotypic functions. Tissue engineering of cell-laden scaffolds/devices for the islets or engineered insulin-producing cells allow for transplantation of these cells to the extra-hepatic sites. The current trend is to develop scaffolds from suitable biomaterials and extra cellular matrix (ECM) proteins that allow for full immune protection, efficient vascularization post-transplantation, and reduction in micro-environmental stress [9-12].

\section{The First Component of the Tissue Engineering Strategy: Need for a Beta Cell Source That Maintains Glucose Responsiveness and Insulin Secretion Properties Similarly to Native Islets}

Generation of beta-like cells from human embryonic stem cells (ESCs) or induced pluripotent stem cells (iPSCs) with direct in vitro differentiation methods has progressed remarkably (Fig. 1) [13-17]. The potential protocols have been continuously optimized to reach higher differentiation efficiency and maturation in mimicking glucose-stimulated insulin secretion patterns similarly to adult human islets [18-20]. Additionally, it has been shown that it is possible to generate functional beta-like cells from the iPSCs of diabetic patients [21-23]. Moreover, pancreatic progenitor cells (PPCs) such as pancreatic exocrine cells, including duct epithelial cells and acinar cells, have been shown to have the ability to differentiate to IPCs [24-26]. Transdifferentiation of PPCs to IPCs has gained gradually more attention in the recent years, although this needs more investigation [27].

In general, the refinement process for maturation of betalike cells in vitro is still in its infancy. Fundamental steps for the development of functional islets depend on our understanding about how different stem cell types and progenitor cells are instructed to differentiate and what are the relationships of the various cell types in the islets [28]. This is particularly challenging since the structure is highly dynamic and relies on a tightly orchestrated cell-cell signaling-based development. Additional factors arise from cell-ECM interactions, inflammatory cytokines, blood components, and nutrients such as glucose. It has been recently shown that WNT4 plays a vital role in the maturation process of functional stem cellderived beta-like cells [20, 29].

Even if the generation of functional IPCs would be successful with the abovementioned cell types, allogeneic betalike cells could trigger the immune system of T1D patients resulting in graft rejection [15]. One strategy to make the IPCs invisible to the host immune system could be to generate universal stem cells by manipulating the genes that encode for human leukocyte antigen (HLA) class I and class II proteins $[30,31]$. Genetic modification approaches including the use of CRISPR/Cas9 gene-editing technology have also been used to eliminate the HLA gene expressions in iPSCs before differentiation into IPCs [32]. In addition, during the differentiation process, not all stem cells can fully differentiate to IPCs and there are always populations of undifferentiated cells that can increase the chance of tumorigenicity of the cells derived from the stem cells. Another strategy to improve the differentiation efficiency and maturation of IPCs as well as increase the safety of these cells is the identification of specific cellsurface markers of the IPCs. Veres et al. has recently reported CD9 as a negative enrichment cell-surface marker for IPCs, combined with $\mathrm{CD} 49 \mathrm{a}$, as a positive surface marker, resulted in $80 \%$ pure IPCs after differentiation [33•]. Another strategy is to place a suicide gene in the cells in order to eliminate them in case of tumorigenicity after transplantation $[34,35]$. Tissue engineering approaches have given a possibility to perform various clinical trials involving ESCs or iPSCs to cure diabetes [32]. Tremendous progress has already been made in the development and generation of IPCs suitable for clinical purposes and therefore could possibly replace the need for islets from cadaveric donors in the near future.

\section{The Benefits of Adding Supporting Cells to Insulin-Producing Cells}

In normal a pancreas, islets are surrounded by exocrine tissue and accessory cells including connective tissue and neurovascular network which both support the islet function and integrate them to the circulatory and nervous systems [36]. The islet isolation procedure destroys the crosstalk between the islets and the accessory cells, resulting in disrupted islet function and survival. Development of pseudo-islets or organoids by combining islets with supporting cells could be 


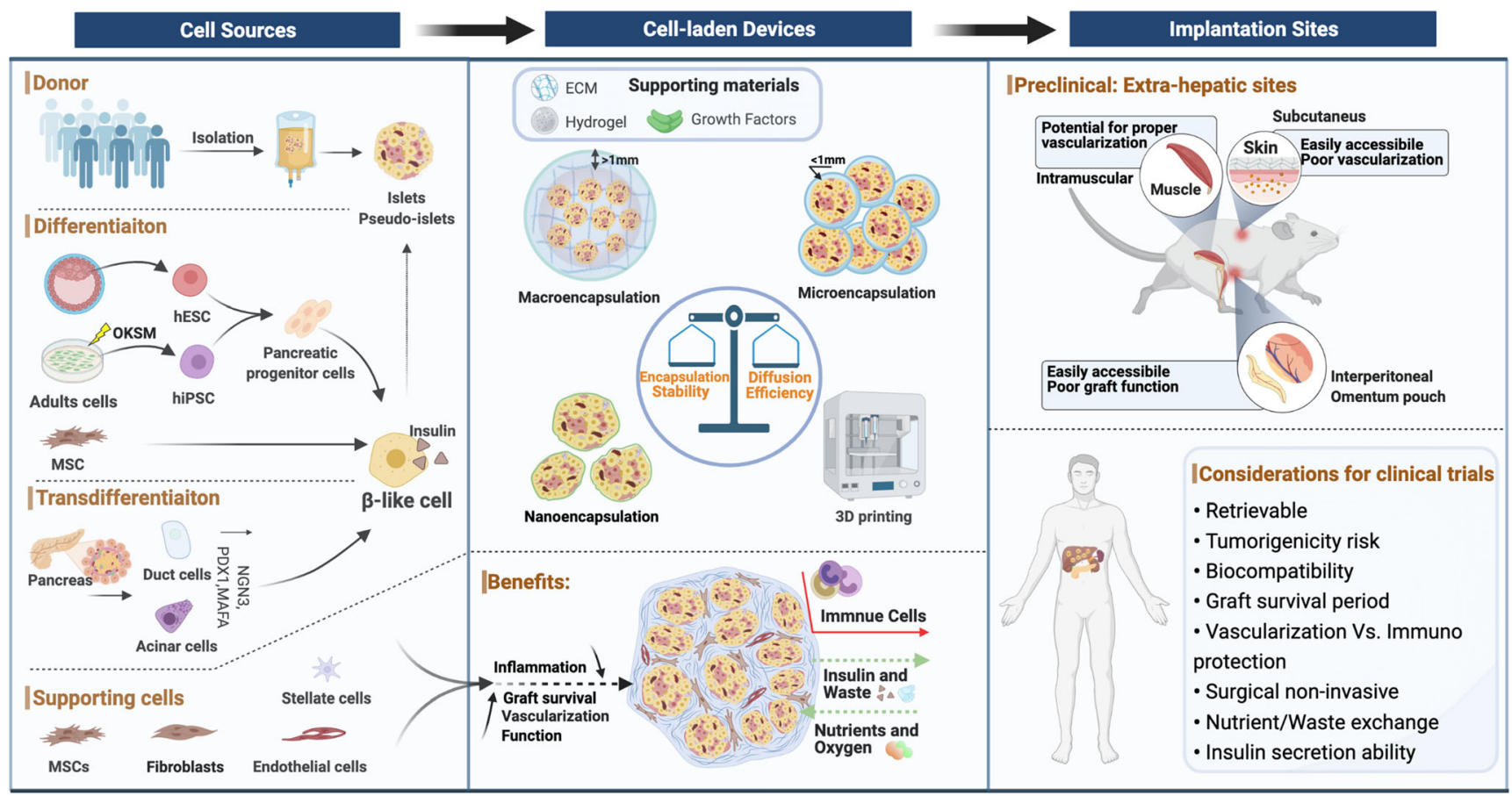

Fig. 1 Three tissue engineering building blocks for generating functional artificial pancreas. The figure illustrates different cell types that have been suggested for bioengineering of insulin-producing cells as well as supporting cells for generation of functional insulin-producing organoids. The image also depicts strategies for creating implantable cell-laden devices in extra-hepatic sites and importantly the criteria for developing cell devices that are applicable for clinical beta cell replacement therapy favorable strategy to create an environment that could mimic the native islet milieu in the pancreatic tissue. Presence of these supporting cells in 3D structured organoids together with IPCs could also favor maturation and function of stem cell-derived insulin-producing cells (Fig. 1).

\section{Mesenchymal Stromal Cells}

Mesenchymal stromal cells (MSCs) are immuneprivileged cells, found in almost all tissues such as bone marrow, adipose tissue, and perinatal derivatives (Fig. 1) $[37,38]$. MSCs are capable of inducing anti-apoptotic and pro-angiogenic effects when co-cultured and cotransplanted with islets [39-41]. Presence of MSCs together with islets has been shown to improve islet function and graft vascularization post-transplantation [42]. The immune-modulatory effects of MSCs protect the newly transplanted islets through activation of Treg cells, which could inhibit activation of $\mathrm{T}$ cells and natural killer cells post islet transplantation [43, 44]. Direct contact of islets and MSCs have reported beneficial effects on glucose responsiveness and insulin secretion of islets in vitro as well as angiogenesis of the graft post-transplantation under kidney capsule of diabetic mice $[45,46]$. It has been suggested that the dynamic crosstalk between the islets and MSCs is required for constitutive secretion of growth factors including VEGF, involving in improved vascularization of the graft and superior insulin secretion capacity of islets [47, 48].

Adipose-derived stromal cells (ASCs) can be easily isolated and expanded by lipoaspiration. Similarly to other MSCs, these cells secrete growth and angiogenic factors upon exposure to hypoxic conditions [42]. Isolating ASCs is a minimally invasive and safe procedure. Therefore, large amount of these cells can be available for clinical applications. Although it is still debated, ASCs have been reported to strongly express higher levels of vascular and intracellular adhesion molecules compared to MSCs, which is beneficial for vascularization and function of the graft post-transplantation [49-51]. Cotransplantation of syngeneic ASCs with marginal allogeneic islet mass showed prolonged graft survival and glucose tolerance in immunocompetent diabetic mice [41]. A graft with ASCs and islets showed well-preserved islet structure and increased vascularization as well as decreased accumulation of $\mathrm{CD} 8+$ and ${ }^{+}, \mathrm{CD} 4+\mathrm{T}$ cells, and macrophages in transplanted mice $[42,52]$.

Encapsulation of islets together with MSCs or ASCs in hydrogel-based beads has also been demonstrated as a strategy to protect the cells from the host immune system [53-55]. Production of growth factors, anti-inflammatory cytokines, and adhesion molecules by MSCs encapsulated with islets has been shown to preserve islet function via increased secretion of anti-oxidant factors and adhesion molecules by islet 
in vitro and reduced pericapsular fibrosis post-transplantation in stablished diabetic mouse model [53, 56-58].

One proposed strategy to improve the survival of islets/ MSCs and increase the outcome of transplantation is pretreating the cells with growth factors. Transplanting rat islets and human ASCs in a fibrin gel pre-treated with epidermal growth factor 2 (EGF2) reduced islet hypoxic damage and increased graft vascularization post-transplantation in the subcutaneous site of T1D mice [59]. However, the short half-life and the release frequency of these factors need to be considered in the study design $[60,61]$.

\section{Endothelial Cells}

Islets are fully vascularized micro-organs and have a unique microvasculature system that is highly specialized for glucose sensing and insulin secretion. Inadequate revascularization of the newly transplanted islets in T1D patients is known as one of the factors for poor islet transplantation outcome [9]. Lack of proper islet graft vascularization post-transplantation induces hypoxic stress and results in loss of islet function [62]. One strategy to improve vascularization of newly transplanted islets is co-transplantation of islets with endothelial cells (ECs). Primary ECs have been shown to induce new blood vessel formation upon co-transplantation with skin fibroblasts, skeletal cells, and stem cell-derived myocardial tissue [63, 64]. Co-transplantation of rat islets and ECs to a diabetic rat model has shown improvement in the surrounding vessel density together with elevated islet graft function [65]. Although having ECs together with islets could accelerate vascularization, the time required for this process is a central issue to be considered in order to prevent ischemia and loss of islets. It takes approximately 7 to 14 days for the newly transplanted islets to get revascularized in the hepatic site [66]. Prevascularization of a transplantation site can improve the in-growth of vessels to the graft post-transplantation. Implantation of the TheraCyte device in the subcutaneous site of diabetic rodents 3 months prior to islet transplantation accelerated diabetes treatment compared to the simultaneous device and islet transplantation [67•]. In another study, implanted cylindrical stainless-steel mesh tubing in the subcutaneous and omentum sites of T1D mice prior to islet transplantation allowed in-growth of vascular structures. Placing islets in this device showed long-term normoglycemia $[65,68]$. On the other site, these approaches promoted fibrosis and foreign body response at the transplantation site and had negative effect on the graft function $[69,70]$. To avoid this, a device-less approach was developed by first implanting a nylon catheter 1 month prior the cell transplantation to create vascularized pocket in the subcutaneous site of T1D mice. The catheter was replaced by islets and the mice obtain normoglycemia for over 100 days post-transplantation $[71 \bullet \bullet]$.

One strategy to improve both islet graft function and also accelerate vascularization of the graft is to take advantage of combining different supporting cells with islets. Transplanting rodent islets with MSCs and fibroblasts in collagenfibronectin hydrogel to the omentum and subcutaneous sites of diabetic mice enhanced vascularization of the scaffold and improved glucose tolerance $[72,73]$. In addition, coaggregation of pancreatic islets, human umbilical ECs (HUVECs), and human MSCs generated a mini-organoid in which HUVECs and MSCs played a key role in revascularization of the organoids post-transplantation $[74,75 \bullet]$.

\section{Pancreatic Stellate Cells}

Pancreatic stellate cells (PSCs) are a multi-functional cell types found in both islets and exocrine tissue of the pancreas [76-78]. Although the knowledge about the inactive form of PSCs is very limited, these cells are known to produce nestin, vimentin, and glial fibrillary acidic protein (GFAP) and have been shown to supply blood flow and provide scaffolding to support epithelial integrity $[79,80]$. Inactivated PSCs are also involved in the maintenance of the ECM components by secretion of metalloproteinases [81]. Inactivated PSCs have also been shown to express toll-like receptors that might support their role in innate immunity [82]. Hepatic stellate cells (HSCs), which have many biological similarities with PSCs, have been reported to express MHC-II proteins, which are needed for interaction with $\mathrm{T}$ cells [83]. Co-transplantation of HSCs with islets has shown to protect the islet allograft from rejection by forming a multi-layered capsule that reduces immunocyte infiltration to the graft [84].

The activated PSCs have been reported to promote fibrosis and secretion of pro-inflammatory cytokines [85]. Moreover, activated forms of PSCs are shown to be involved in pancreatic diseases such as glucose intolerance, fibrosis, and pancreatitis [86-88]. The triggers for the activation of these cells are not yet fully understood. However, conditions such as hypoxia, hyperglycemia, and presence of endotoxins are suggested to be involved in production of local cytokines from macrophages in islets and shift from inactivated to activated PSCs $[89,90]$. Therefore, more investigation is required to clarify the role of the activated PSCs on islet health. Fibrosis is one of the factors that deteriorate the long-term survival of the islets within cell devices. Since activated PSCs can be involved in islet fibrosis, understanding the molecular mechanisms of PSC activation is vital before these cells can be used together with insulin-producing organoids. 


\section{Second Component of the Tissue Engineering Strategy: Generation of Supporting Cell-Laden Scaffolds for Insulin-Producing Cells}

Different scaffold fabrication and encapsulation methods provide protective options to keep the cells isolated from the direct contact with auto- and allo-immune responses (Fig. 1). Encapsulation strategies are based on the distance between the cells inside the device and the host environment [91]. Macroencapsulation involves encasing a large number of cells within a device with the size of more than $1 \mathrm{~mm}$. The advantages of the macro-scale scaffolds are the tunability of the shape, membrane parameters, and pore size with wide spectrum of different fabrication methods. Due to the relatively large size, preferably one device would be enough to deliver the curative cell dose [92]. In contrast, microencapsulation approach uses many micro-scale capsules with the diameter of less than $1 \mathrm{~mm}$ with each capsule containing a single cell or an islet. Many of the benefits for microencapsulation are attributed to the spherical shape of the capsule, as it maximizes the surface to volume ratio and promotes the passive diffusion of oxygen, exchange of nutrient, and waste products [93]. In both encapsulation strategies, the devices are mainly made of semipermeable hydrogel-based biomaterials with the cells embedded in the hydrogel. The third encapsulation strategy is the nanoencapsulation method in which a thin layer of hydrogel-based material is placed on the surface of an islet or a cell aggregate [94]. The final cross-linked hydrogel layer generates a nanometric conformal coating around the surface of the cells [95]. Selected studies in which hydrogel-based materials are used for generation of encapsulation devices are presented in Table 1.

The key function of an encapsulation device is to provide an immune-protective environment for cells that allows normal insulin secretion in response to blood glucose, while maintaining islet viability with effective nutrient and waste exchange capability. An optimal device would keep cytotoxic $\mathrm{T}$ cells and immune cells out of the islet capsule and also protect the islets from antibodies and cytokines that might be detrimental to their survival [67•]. Some of these immune mediatory molecules are similar in size as insulin or other necessary nutrients which means it is not possible to avoid the entry of all immune-related molecules [115].

The BAir device is an example of a macroencapsulation device, which gives the islets immune protection with a thin hydrophilized teflon membrane impregnated with alginate and also supplies the cells with oxygen by daily refills of oxygen- $\mathrm{CO}_{2}$ mixture $[98,116]$. Encapsulation of allogeneic beta-like cells is twice as important, not only to avoid immune rejection of the cells post-implantation but also to act as a protection barrier against undifferentiated pluripotent cell population that might have harmful tumorigenic properties
$[117 \bullet \bullet, 118]$. In 2014, a clinical trial was performed in T1D patients to evaluate the safety and efficiency of ViaCyte VC$01^{\mathrm{TM}}$, which is a macroencapsulation device with human ESCs-derived pancreatic progenitor cells (ClinicalTrials.gov, identifier: NCT02239354). Although the device is immuneprotective and does not allow entry of host immune cells, it does not promote vascularization of the cells within the device and consequently showed poor insulin-producing cell function post-implantation $[119,120]$. Another updated macroencapsulation device, $\mathrm{VC}-02^{\mathrm{TM}}$, that contains ESCsderived pancreatic progenitor cells allows vascularization of the device as it is fabricated with numerous small holes for ingrowth of vessels. However, this device is not immuneprotective which means immunosuppressive regimen for these patients are required (ClinicalTrials.gov, identifier: NCT03163511). Other selected clinical trials regarding encapsulated islet derives for T1D patients are presented in Table 2.

The main advantages of the macroencapsulation cell devices over micro- and nano-devices are the easier implantation methods and retrievability of the devices in case of a graft failure or any other complications [127]. However, the main limitations of the macroencapsulation devices are the poor exchange and diffusion rates of nutrients and oxygen, which are dependent on the device parameters such as the chosen material, thickness, or reservoir size. These variables alter the kinetics of insulin release, which might lead to severe problems such as hypoglycemia $[128,129]$. Therefore, implantation of such devices to sites that have low vascularization capabilities could be even more challenging in terms of nutrient exchange and cell viability post-implantation [130].

In strategies such as microencapsulation, the volume of the transplanted islets is lower than the volume of the hydrogel material due to the possible presence of empty micro-capsules within the cell/capsule mix [131]. In this case, some hydrogels such as alginate, which is widely used for encapsulation procedures, can generate foreign body responses, amyloid formation, and fibrosis, leading to device failure [132, 133]. Nanoencapsulation technology can be more beneficial as each capsule is fabricated according to the size and shape of an islet. Therefore, this strategy allows higher cell to biomaterial ratio $[134 \bullet \bullet, 135]$. However, hydrogel-based biomaterials can be very fragile and unstable [136]. Improper coating of the islets in this approach might leave some cells exposed to the host environment that results in graft failure [137-139].

\section{D Bioprinting}

3D bioprinting technology is an innovative fabrication method where cells are $3 \mathrm{D}$ printed together with hydrogels. In a way, this is also a macroencapsulation strategy, as it provides the possibility to fabricate devices with multiple islets or 
Table 1 Selected studies on different biomaterials and islet encapsulation methods for beta cell replacement therapy

\begin{tabular}{|c|c|c|c|c|}
\hline Biomaterial & Methods & Cells & In vivo outcome & Reference \\
\hline $\begin{array}{l}\text { Polytetrafluoroethylene } \\
\text { (PTFE) }\end{array}$ & TheraCyte macroencapsulation device & $\begin{array}{l}\text { Pancreatic } \\
\text { progenitor } \\
\text { cells }\end{array}$ & $\begin{array}{l}\text { TheraCyte device implanted subcutaneously in } \\
\text { non-diabetic mouse model reported functional } \\
\text { insulin-producing cells and high level of plasma } \\
\text { c-peptide in response to blood glucose } 20-30 \\
\text { weeks post-implantation }\end{array}$ & {$[96]$} \\
\hline Alginate/collagen matrix & $\begin{array}{l}\text { Multi-layered cell sheet planar device with islets } \\
\text { in central collagen matrix layer. Two external } \\
\text { alginate layers were designed for immune } \\
\text { protection }\end{array}$ & Porcine islets & $\begin{array}{l}\text { Islet sheets were implanted subcutaneously in } \\
\text { diabetic non-human primates. The animals } \\
\text { achieved normoglycemia and the device } \\
\text { maintained the status up to } 6 \text { months } \\
\text { post-implantation without immunosuppressive } \\
\text { regimen. A strong immune response was } \\
\text { observed }\end{array}$ & {$[97]$} \\
\hline $\begin{array}{l}\text { Alginate/polyether ether } \\
\text { ketone }\end{array}$ & $\begin{array}{l}\text { BAir disk-shaped device made of clinical grade } \\
\text { polyether ether ketone. The device contains } \\
\text { encapsulated islets in alginate }\end{array}$ & Rat islets & $\begin{array}{l}\text { Subcutaneous implantation of ßAir device } \\
\text { maintained glucose levels within the } \\
\text { physiological levels in diabetic rat model up to } 3 \\
\text { months post-implantation. This is followed by } \\
\text { vascularization of the device and improvement } \\
\text { in glucose tolerance and insulin secretion }\end{array}$ & {$[98]$} \\
\hline Alginate/DM18-pectin & $\begin{array}{l}\text { Microencapsulation of islets with droplet } \\
\text { generator and cross-linked with } \mathrm{CaCl}_{2}\end{array}$ & Rat islets & $\begin{array}{l}\text { Encapsulated islets implanted to the peritoneal } \\
\text { cavity of diabetic C57BL/ } 6 \text { mice induced } \\
\text { normoglycemia up to } 200 \text { days and inhibited } \\
\text { pericapsular fibrosis }\end{array}$ & [99] \\
\hline Alginate & $\begin{array}{l}\text { Purified mannuronic acide (high-M) alginate was } \\
\text { used to generate microencapsulated islets } \\
\text { followed by cross-linking with } \mathrm{BaCl}_{2}\end{array}$ & Porcine islets & $\begin{array}{l}\text { Diabetic B6AF1 mice transplanted with the } \\
\text { encapsulated porcine islets at the intraperitoneal } \\
\text { site reported normalization of blood glucose } \\
\text { levels up to } 190 \text { days post-implantation. } \\
\text { Explanted capsules were free of fibrotic tissue. } \\
\text { An immune response of IgG and IgM subtypes } \\
\text { was observed post-transplantation }\end{array}$ & {$[100]$} \\
\hline Alginate & $\begin{array}{l}\text { Alginate microencapsulation with inner coating of } \\
\text { poly-L-lysine and outer coating of strontium }\end{array}$ & Mouse islets & $\begin{array}{l}\text { Microencapsulated islet allografts stayed functional } \\
\text { up to } 553 \text { days in diabetic NOD mice without } \\
\text { immunosuppression regimen and } 95 \text { days in } \\
\text { immunosuppressed NHPs post-implantation. } \\
\text { Two NHPs received MSCs and oxygen therapy } \\
\text { prior to islet transplantation and reported } \\
\text { improvement in the graft function with no sign of } \\
\text { fibrosis responses }\end{array}$ & {$[101]$} \\
\hline Alginate & Micro-capsules barium-gelled alginate & Porcine islets & $\begin{array}{l}\text { Immunosuppressed, diabetic NHPs transplanted at } \\
\text { the intraperitoneal site with encapsulated porcine } \\
\text { islets showed reduction in hyperglycemic } \\
\text { episodes and improvement in metabolic } \\
\text { function. No signs of fibrosis was observed }\end{array}$ & {$[102 \bullet \bullet]$} \\
\hline PEG-based hydrogel & $\begin{array}{l}\text { Micro-capsules consist of hydrogel core } \\
\text { cross-linked with a non-degradable PEG and a } \\
\text { vasculogenic outer layer }\end{array}$ & Rat islets & $\begin{array}{l}\text { Implementation of encapsulated islets with } \\
\text { vasculogenic hydrogel layer enhanced vascular } \\
\text { density within the omentum transplant site This } \\
\text { improved islet viability in a syngeneic diabetic } \\
\text { rat model }\end{array}$ & [103] \\
\hline Alginate/resin & $\begin{array}{l}\text { 3D printed resin rings coated with alginate and } \\
\text { cross-linked with } \mathrm{CaCl}_{2} \text { and } \mathrm{BaCl}_{2}\end{array}$ & Rat islets & $\begin{array}{l}\text { Devices were coated with } 500 \text { islets per mouse and } \\
\text { implanted to the intraperitoneal space of } \\
\text { C57BL/ } 6 \text { mice. The devices normalized the } \\
\text { blood glucose and maintained islet function } 12 \\
\text { weeks post-implantation }\end{array}$ & {$[104]$} \\
\hline $\begin{array}{l}\text { Alginate/perfluorodecalin } \\
\text { (PFD) }\end{array}$ & $\begin{array}{l}\text { Islet-hydrogel micro-capsules cross-linked with } \\
\mathrm{BaCl}_{2} \text {. PFD was added as an oxygen carrier }\end{array}$ & $\begin{array}{l}\text { Rat and mouse } \\
\text { islets }\end{array}$ & $\begin{array}{l}200 \text { and } 300 \text { islet beads per mouse were implanted } \\
\text { to the peritoneal cavity of C57BL/6 mice. Islet } \\
\text { beads normalized blood glucose for up to } 48 \\
\text { days post-transplantation }\end{array}$ & {$[105]$} \\
\hline Gelatin & $\begin{array}{l}\text { Biodegradable islet pockets were fabricated from } \\
\text { gelatin sheets supplemented with bFGF and } \\
\text { sodium hyaluronate }\end{array}$ & Rat islets & $\begin{array}{l}\text { Empty sheets were implanted to the dorsal } \\
\text { subcutaneous site of rats followed by injection of } \\
\text { viscous sodium hyaluronate-bFGF mixture } \\
\text { around the sheets. After day } 7 \text { post-implantation, } \\
\text { islets were injected to the sheets. No } \\
\text { immunosuppressive regimen was used. } \\
\text { Vascularized tissue was observed around the } \\
\text { sheets day } 7 \text { post-implantation. Glycaemia was } \\
\text { restored up to100 days }\end{array}$ & {$[106]$} \\
\hline
\end{tabular}


Table 1 (continued)

\begin{tabular}{|c|c|c|c|c|}
\hline Biomaterial & Methods & Cells & In vivo outcome & Reference \\
\hline Silk/heparin & $\begin{array}{l}\text { Heparin sodium salt and silk fibroin solutions } \\
\text { were crystallized to cylinder-shaped molds. } \\
\text { Finalized scaffolds were cut to cylinder-shaped } \\
\text { slices }\end{array}$ & Mouse islets & $\begin{array}{l}300 \text { islets per cylinder were transplanted to the } \\
\text { epididymal fat pads of C57BL/6 mice. } \\
\text { Normoglycemia was achieved }<1 \text { week } \\
\text { post-transplantation and maintained for } 1 \text { year } \\
\text { alongside with the efficient intra-islet } \\
\text { vascularization }\end{array}$ & {$[107]$} \\
\hline Collagen/alginate/PVA & $\begin{array}{l}\text { Polyvinyl alcohol (PVA) sponge disks with } \\
\text { alginate with VEGF. Islets were placed in } \\
\text { peripheral cavities of the disk }\end{array}$ & Mouse islets & $\begin{array}{l}\text { Disks that contained } 500 \text { islets were implanted to } \\
\text { the subcutaneous pocket of C57Bl/6 mice. The } \\
\text { grafts reversed diabetes in mice after } 20 \text { days } \\
\text { post-implantation and maintained } \\
\text { normoglycemia up to } 116 \text { days. Disks with } \\
\text { VEGF-enriched alginate reported lower levels of } \\
\text { islet necrosis and higher levers of vascular } \\
\text { density }\end{array}$ & {$[108]$} \\
\hline PEG/heparin & $\begin{array}{l}\text { Highly porous PEG-heparin scaffolds were } \\
\text { fabricated using cryogelation technique }\end{array}$ & $\begin{array}{l}\text { Mouse islets } \\
\text { and MSCs }\end{array}$ & $\begin{array}{l}\text { Devices containing } 5 \times 10^{5} \text { MSCs and } 100 \text { islets } \\
\text { were implanted to the subcutaneously site of } \\
\text { C57BL6/J mice. Although thin fibrous layer was } \\
\text { observed after explantation of the devices on day } \\
7 \text { post-implantation, the islets and MSCs in the } \\
\text { scaffolds were intact }\end{array}$ & [109] \\
\hline PVA/silicone/VEGF & $\begin{array}{l}\text { PVA/silica fiber membranes conjugated with } \\
\text { VEGF }\end{array}$ & Mouse islets & $\begin{array}{l}\mathrm{SiO}_{2} \text {-VEGF nano-fibers containing } 200 \text { IEQ islets } \\
\text { were transplanted to a pre-vascularized area in } \\
\text { the subcutaneous site of diabetic mice. } \\
\text { Transplanted animals with islet nano-fibers } \\
\text { maintained normoglycemia up to } 70 \text { days } \\
\text { post-implantation }\end{array}$ & {$[110]$} \\
\hline $\begin{array}{l}\text { Medical-grade polylactic } \\
\text { acid }\end{array}$ & $\begin{array}{l}\text { 3D bioprinted scaffolds were pretreated with } \\
\text { VEGF-enriched platelet gel to increase } \\
\text { vascularization }\end{array}$ & Human islets & $\begin{array}{l}\text { Scaffolds were implanted } 4 \text { weeks prior to the } \\
\text { injection of human islets to the subcutaneous site } \\
\text { of the nude non-diabetic mice. Followed by } 2 \\
\text { doses of human islet ( } 2000 \text { IEQ, and } 2000 \text { IEQ, } \\
\text { second dose } 12 \text { weeks later). The islets stayed } \\
\text { viable as the scaffolds protected them from } \\
\text { hypoxia throughout the study }\end{array}$ & {$[111]$} \\
\hline Alginate/gelatine & $\begin{array}{l}\text { Coaxial bioprinting of filaments with islets in the } \\
\text { core and endothelial progenitor cells in the } \\
\text { shell layer }\end{array}$ & $\begin{array}{l}\text { Mouse islets } \\
\text { and } \\
\text { endothelial } \\
\text { progenitor } \\
\text { cells }\end{array}$ & $\begin{array}{l}\text { The scaffolds implanted in C57BL/ } 6 \text { mice were } \\
\text { stable for up to } 21 \text { days post-implantation. } \\
\text { Vessel formation was observed after day } 14\end{array}$ & {$[112]$} \\
\hline PEG & Nanoencapsulated PEG-coated islets & Porcine islets & $\begin{array}{l}\text { PEG-coated porcine islets transplanted to diabetic } \\
\text { rat model reported reduction in the blood glucose } \\
\text { levels to the normoglycemic range; however, } \\
\text { animals returned to hyperglycemia } 60-70 \text { days } \\
\text { post-implantation }\end{array}$ & [113] \\
\hline $\mathrm{PEG} /$ heparin & $\begin{array}{l}\text { Layer-by-layer nanoencapsulation of islets with } \\
\text { PEG combined with heparin }\end{array}$ & $\begin{array}{l}\text { Non-human } \\
\text { primate }\end{array}$ & $\begin{array}{l}\text { Nanoencapsulated islets transplanted in } \\
\text { Cynomolgus monkeys showed c-peptide } \\
\text { positive graft } 108 \text { post-implantation. } \\
\text { Encapsulated islets with heparin also reported } \\
\text { reduction in factors responsible for IBMIR }\end{array}$ & [114] \\
\hline
\end{tabular}

insulin-producing cell clusters encapsulated in different biomaterials [140]. The most common 3D bioprinting methods are (1) inkjet bioprinting, (2) microextrusion-based bioprinting, (3) laser-based, and (4) light-based bioprinting. Coaxial bioprinting is also a type of the extrusion bioprinting, which allows co-printing of two biomaterials, each containing different types of cells. More detailed information about each method is discussed in these review articles [12, 140]. Marchioli et al. were the first to bioprint directly beta cells and islets mixed with a hydrogel. Their studies confirm the printability of insulin-producing cells and islets. However, the cells showed diminished function and insulin secretion in response to glucose [141. Various studies have acknowledged similar viability and functionality challenges post-printing later on as well [93, 142•]. Enrichment of the chosen biomaterial with decellularized native tissues such as pancreas, adipose, heart, and cartilage is one strategy to mimic tissue-specific biological cues and create biomimetic environment for islets [143]. However, bioprinted cell devices with this strategy still lack long-term cell function post-printing [93, 143]. 
Table 2 Relevant selected clinical studies with different encapsulation strategies for beta cell replacement therapy

\begin{tabular}{|c|c|c|c|c|}
\hline Biomaterial & Cells & Method & Clinical trial outcome & Reference \\
\hline $\begin{array}{l}\text { Encapta VC-01 } \\
\quad \text { device }\end{array}$ & $\begin{array}{l}\text { Pancreatic } \\
\text { progenitor } \\
\text { cells generated } \\
\text { from ESCs }\end{array}$ & $\begin{array}{l}19 \text { T1D patients were implanted subcutaneously } \\
\text { with the device }\end{array}$ & $\begin{array}{l}\text { The device provided immune protection against } \\
\text { the host adaptive immune system with no } \\
\text { evidence of allogenic or autoimmune } \\
\text { rejection. In addition, the potential } \\
\text { insulin-producing cell survived for } 24 \text { months } \\
\text { post-implantation }\end{array}$ & {$\left[120^{\bullet}\right]$} \\
\hline BAir device & $\begin{array}{l}\text { Allogeneic } \\
\text { human islets }\end{array}$ & $\begin{array}{l}\text { A case report of a } 63 \text {-year-old T1D patient } \\
\text { implanted with BAir device containing } 2100 \\
\text { EIQ/kg body weight of allogeneic islets }\end{array}$ & $\begin{array}{l}\text { Graft function was maintained for } 10 \text { months } \\
\text { with controlled blood glucose levels and } \\
\text { regulation of insulin secretion without } \\
\text { administration of any immunosuppressive } \\
\text { agents }\end{array}$ & {$[116]$} \\
\hline BAir device & $\begin{array}{l}\text { Allogeneic } \\
\text { human islets }\end{array}$ & $\begin{array}{l}\text { The safety and efficiency of the BAir device } \\
\text { containing } 155,000-180,000 \text { IEQ was } \\
\text { evaluated in four T1D patients with follow-up } \\
\text { period for 3-6 months post-implantation }\end{array}$ & $\begin{array}{l}\text { Implantation of the } \beta \text { Air device was safe and } \\
\text { successfully prevented rejection of the } \\
\text { transplanted islets. However, only low levels } \\
\text { of circulating c-peptide were observed with } \\
\text { no impact on metabolic control. Presence of } \\
\text { fibrotic tissue with immune cells was } \\
\text { observed in the surroundings of capsules. } \\
\text { Recovered islets from the devices displayed } \\
\text { poor glucose-stimulated insulin response and } \\
\text { amyloid formation }\end{array}$ & {$[121]$} \\
\hline $\begin{array}{l}\text { Microencapsulated } \\
\text { islets }\end{array}$ & $\begin{array}{l}\text { Allogeneic } \\
\text { human islets }\end{array}$ & $\begin{array}{l}\text { A case report of a T1D patient transplanted with } \\
15,000 \mathrm{IEQ} / \mathrm{kg} \text { of alginate microencapsulated } \\
\text { islets in the intraperitoneal site }\end{array}$ & $\begin{array}{l}\text { Transplantation of microencapsulated islets } \\
\text { resulted in glycemic control and insulin } \\
\text { independence for up to } 9 \text { months } \\
\text { post-transplantation. The patient received } \\
\text { immunosuppressive regimen due to their } \\
\text { previous renal transplant }\end{array}$ & {$[122]$} \\
\hline $\begin{array}{l}\text { Microencapsulated } \\
\text { islets }\end{array}$ & $\begin{array}{l}\text { Allogeneic } \\
\text { human islets }\end{array}$ & $\begin{array}{l}\text { Two T1D patients were transplanted with a total } \\
\text { number of } 400,000 \text { and } 600,000 \\
\text { microencapsulated islets in the intraperitoneal } \\
\text { site without administration of } \\
\text { immunosuppressive agents }\end{array}$ & $\begin{array}{l}\text { Transplantation procedure was non-invasive } \\
\text { and devoid of side effects. Although the } \\
\text { patients were unable to withdraw exogenous } \\
\text { insulin, the decline in the frequency of } \\
\text { weekly hypoglycemic episodes and } \\
\text { responsiveness to OGTT indicated the graft } \\
\text { metabolic function }\end{array}$ & {$[123]$} \\
\hline $\begin{array}{l}\text { Microencapsulated } \\
\text { islets }\end{array}$ & $\begin{array}{l}\text { Allogeneic } \\
\text { human islets }\end{array}$ & $\begin{array}{l}\text { Four T1D patients were transplanted } \\
\text { intraperitoneal with alginate } \\
\text { microencapsulated islets }\end{array}$ & $\begin{array}{l}\text { All patients had serum c-peptide response, both } \\
\text { in basal and after stimulation, throughout } 3 \\
\text { years of post-transplant follow-up. This is } \\
\text { followed by improved levels of blood glucose } \\
\text { and HbA1c levels. Anti-MHC class I-II and } \\
\text { GAD65 antibodies were negative in all } \\
\text { patients } 3 \text { years post-transplantation }\end{array}$ & {$[124]$} \\
\hline $\begin{array}{l}\text { Microencapsulated } \\
\text { islets }\end{array}$ & Porcine islets & $\begin{array}{l}4 \text { T1D patients were transplanted with total } \\
\text { number of } 10,000 \text { and } 20,000 \mathrm{IEQ} / \mathrm{kg} \text { in } \\
\text { intraperitoneal cavity without } \\
\text { immunosuppressive regimen }\end{array}$ & $\begin{array}{l}\text { All four patients showed improvement in the } \\
\text { levels of HbA1c }(<7 \%) \text { with reduction in the } \\
\text { frequency of unaware hypoglycemia and } \\
\text { daily dose of insulin injection for }>600 \text { days } \\
\text { post-transplantation }\end{array}$ & {$[125]$} \\
\hline $\begin{array}{l}\text { PEG-coated } \\
\text { nanoencapsulat- } \\
\text { ed islets }\end{array}$ & Porcine islets & $\begin{array}{l}\text { Two patients with the age of } 25 \text { and } 30 \text { were } \\
\text { transplanted with nanoencapsulated porcine } \\
\text { islets subcutaneously to the back and the } \\
\text { abdomen without immunosuppressive } \\
\text { regimen }\end{array}$ & $\begin{array}{l}\text { Although the recipients experienced a reduction } \\
\text { in the numbers of hyper- and hypoglycemic } \\
\text { episodes, neither of the subjects achieved } \\
\text { insulin independence }\end{array}$ & {$[126]$} \\
\hline
\end{tabular}

To overcome poor vascularization and improve oxygenation and nutrient supply of bioprinted islet structures, artificial vascular structures could be included to the device design. These kind of structures are printed with the help of sacrificial biomaterials such Pluronic F127 or gelatin that create micro-channel network inside the material. After printing and cross-linking of the biomaterial, the sacrificial part is removed, which leads to an empty vasculature network inside the printed scaffold. Optionally, this kind of network can be seeded with suitable cells such as ECs to endothelialized the walls and mimic vascular tissue for in vitro studies $[144,145]$. 
Bioprinting supporting cells together with the pancreatic islets to a multi-layer scaffold is another strategy to promote vascularization and immune protection of the bioprinted islet structures. Adding ASCs to islets gives the opportunity to generate a 3D bioprinted multi-cellular scaffold structure that can improve islet function and survival in vitro [146]. However, there is so far no evidence showing the functional 3D bioprinted islet graft that improves glucose regulation in diabetic mice post-implantation. Interestingly, 3D bioprinted islets in the inner core and endothelial progenitor cells (EPCs) in the outer shell of alginate/gelatin-based hydrogel demonstrated maintenance of normoglycemia for up to 80 days posttransplantation in diabetic mice [112]. Natural hydrogels that are mainly used for bioprinting applications display structural resemblance to ECM and have better biocompatibility compared to synthetic biomaterials. However, they are fragile and not stable enough to guarantee long-term survival of islet structures until the cells remodel the material with their own ECM and complete the vascularization process [147]. Mixing natural hydrogels with synthetic hydrogels such as Pluronic and polyethylene glycol (PEG) improves the mechanical properties of the biomaterial and increases tunability of these materials for fabricating cell devices. Selected encapsulation studies regarding $3 \mathrm{D}$ bioprinting technology and different biomaterials to create islet scaffolds are presented in Table 1 . Although bioprinting approach is a versatile and revolutionary technology, generating a whole organ using this technique is still in its infancy. Clinical translation of this strategy still needs further development of novel clinical-grade biomaterials with tunable properties to provide better diffusion, vascularization, and additionally decrease the risk of host immune responses toward the $3 \mathrm{D}$ bioprinted structures.

\section{Third Component of the Tissue Engineering Strategy: Optimization of Implantation Site}

Alternative extra-hepatic sites for transplantation of islets or insulin-producing organoids need to be accessible for observation and easy to explant in case of complications. In addition, transplanting to these sites must be technically safe and minimally invasive without causing any severe complications post-transplantation. Vascularization of the grafts in the extrahepatic transplantation sites is essential to avoid microenvironmental stress induced by the lack of oxygen and nutrients post-transplantation (Fig. 1) [148].

Skeletal muscles have been proposed as an extra-hepatic alternative site for transplanting the islets [148]. Proper revascularization of transplanted human islets has been observed in the intramuscular site in immunocompromised mice. Additionally, results from few cases of autotransplanted pancreatectomized patients have shown promising data for the skeletal muscle tissue as a potential extra-hepatic site for islet transplantation [149]. However, testing this site only on a few islet allotransplantation patients reported inconsistent results regarding the islet function and local inflammatory responses [150]. Generating biological scaffolds for islets from ECM enriched with growth factors has reported to increase insulin response and viability of the graft transplanted intramuscular in diabetic mice $[151,152]$. Intramuscular transplantation site has also given the possibility to monitor the scaffold and the graft vascular density with positron emission tomography (PET) [152].

Subcutaneous site stands out from the other tissue types as it has notable advantages such as its accessibility and extensive surface area that is suitable for scaling up the scaffold size to contain required number of islets for clinical islet transplantation [148, 153-156]. Recently, implantation of type I collagen-based islet scaffolds in subcutaneous site of diabetic mice with and without use of immune-suppressive medications showed reversal of diabetes and improved angiogenesis in both mouse models [157]. One disadvantage of subcutaneous site is the poor graft vascularization capacity due to the low oxygenation of the skin tissue [158]. Enriching scaffolds with growth factors can overcome this limitation. However, the short half-life of growth factors does not make this strategy optimal for long-term graft function [159, 160]. It is vital to consider that the route for insulin secretion is systemic drainage in subcutaneous site, whereas the normal route for insulin delivery is the portal vein [148]. Therefore, choosing a site such as the omentum that allows for insulin drainage via portal vein is more physiological for the islets [161]. The omentum is highly vascularized and easily accessible, which makes it suitable as an extra-hepatic transplantation site [162-164]. A biological islet scaffold was developed by mixing the islets with the plasma of the recipient followed by transplantation to the omentum. By adding thrombin to the scaffold at the transplantation site, fibrinogen in the plasma converted to fibrin and polymerized the scaffold with the islets inside [165]. Transplantation of this biodegradable scaffold in the omentum of diabetic rats and non-human primates reported less islet inflammation and improved glucose regulation [163, 165]. Although this approach was tested in 3 T1D patients, the study was stopped after poor graft function in 2 out of the 3 patients. Therefore, our current understanding on this site is still limited to preclinical studies. More comprehensive stepwise approaches need to be developed in order to broaden our knowledge on finding an alternative and suitable implantation site for insulin-producing devices.

\section{Future Perspectives and Conclusion}

Three current building blocks of tissue engineering to advance the beta cell replacement therapy for patients with T1D are (1) alternative beta cell sources and supporting cells to generate 
insulin-producing organoids, (2) scaffolds or devices for homing the cells, and (3) identifying a suitable implantation site (Fig. 1). Despite of the extensive development for generating IPCs, these cells do not yet fully resemble native human islet function. More research needs to be conducted to understand the intricacies of the glucose regulation and the crosstalk between different cell types in a native islet, as it will provide vital knowledge for maturation of the generated IPCs [166, 167]. Bioengineering of insulin-producing organoids with IPCs and supporting cells is a promising step to improve maturity and intra-vascularization of these organoids. However, upscaling methods to differentiate IPCs and also expand IPCs and supporting cells to the required number for clinical applications are costly and labor intensive [168]. In addition, various analyses need to be performed to increase the safety of the produced cells, which add up to the cost and the needed time to have the cells applicable for clinical purposes [169].

Macroencapsulation devices have become an attractive strategy for clinical applications, as they can contain the curative cell dose for diabetic patients. Having the cells in a close contact within these device is suggested to be a vital factor for optimal blood glucose regulation [115]. Encapsulation as a method helps to immune-protect cells from the host environment. However, the limitations of this method are poor vascularization and nutrient exchange that need to be solved for optimal device function. For example, devices with permeable membrane structures that allow in-growth of vessels into the device can strongly aid with the graft function. Nevertheless, development of a device that would have these two most desired qualities, (i) an immuneprotective membrane and (ii) viability promoting qualities, is yet to be discovered. Optimal insulin-producing graft function is also dependent on the biocompatibility of the materials used to develop potential devices. Synthetic biomaterials have optimal and defined mechanical properties but lack the biocompatibility aspect. On the other hand, natural biomaterial hydrogels and ECM-derived proteins and cues have excellent biocompatibility and regenerative capacity to support cell function but these lack mechanical tunability and robustness. These two strategies as combined and mixed with cells could potentially provide excellent opportunities to develop suitable, stable, and biocompatible functional islet devices [170-172]. Foreign body responses and fibrosis compromise the functionality of the devices for insulinproducing cells. Understanding not only the chemical properties of biomaterials but also the molecular biology and cell signaling pathways behind fibrosis post-implantation could lift up our knowledge to bioengineer more biocompatible devices [173, 174].

In this review, we have discussed the central elements of the tissue engineering field for generating artificial pancreas. The progress in the development of these strategies to engineer islet devices that would mimic the functions of an endocrine pancreas has made enormous steps in the recent years. All three building blocks of tissue engineering that we have discussed in this review need to come together in order to have a fully functional, safe, and translatable islet or insulin-producing organoid device for clinical beta cell replacement therapy.

Abbreviations IEQ, Islet equivalent; IBMIR, Induced blood-mediated inflammatory reaction; T1D, Type 1 diabetes; PET, Positron emission tomography; VEGF, Vascular endothelial growth factor; FGF, Fibroblast growth factor; HGF, Hepatocyte growth factor; PEG, Polyethylene glycol; ESC, Embryonic stem cell; iPSC, Induced pluripotent stem cell; MSC, Mesenchymal stromal cell; PPC, Pancreatic progenitor cell; ASC, Adipose-derived stromal cell; PSC, Pancreatic stellate cell; TE, Tissue engineering; IPC, Insulin-producing cell; ECM, Extra cellular matrix; HbA1c, Hemoglobin A1c; EC, Endothelial cell

Availability of Data and Material (Data Transparency) Not applicable. Code Availability (Software Application or Custom Code) Not applicable.

Author Contribution All authors have contributed in writing and editing of this review.

Funding Open access funding provided by University of Oslo (incl Oslo University Hospital). This work was partly supported by the Research Council of Norway through its Centers of Excellence funding scheme, project number 262613. Financial support from UiO:Life Science is gratefully acknowledged.

\section{Declarations}

Conflict of Interest The authors declare no competing interests.

Human and Animal Rights and Informed Consent This article does not contain any studies with human or animal subjects performed by any of the authors.

Additional Declarations for Articles in Life Science Journals That Report the Results of Studies Involving Humans and/or Animals Not applicable.

Ethics Approval (Include Appropriate Approvals or Waivers) Not applicable.

Consent to Participate (Include Appropriate Statements) Not applicable.

Consent for Publication (Include Appropriate Statements) Not applicable.

Open Access This article is licensed under a Creative Commons Attribution 4.0 International License, which permits use, sharing, adaptation, distribution and reproduction in any medium or format, as long as you give appropriate credit to the original author(s) and the source, provide a link to the Creative Commons licence, and indicate if changes were made. The images or other third party material in this article are included in the article's Creative Commons licence, unless indicated otherwise in a credit line to the material. If material is not included in the article's Creative Commons licence and your intended use is not permitted by statutory regulation or exceeds the permitted use, you will need to obtain permission directly from the copyright holder. To view a copy of this licence, visit http://creativecommons.org/licenses/by/4.0/. 


\section{References}

Papers of particular interest, published recently, have been highlighted as:

- Of importance

- Of major importance

1. Barton FB, Rickels MR, Alejandro R, Hering BJ, Wease S, Naziruddin B, et al. Improvement in outcomes of clinical islet transplantation: 1999-2010. Diabetes Care. 2012;35(7):1436-45.

2. Gerber PA, Lehmann R. Islet transplantation in type I diabetes mellitus. Diabetologe. 2015;11(7):545-52.

3. Vantyghem MC, de Koning EJP, Pattou F, Rickels MR. Advances in beta-cell replacement therapy for the treatment of type 1 diabetes. Lancet. 2019;394(10205):1274-85.

4. Shapiro AMJ, Lakey JRT, Ryan EA, Korbutt GS, Toth E, Warnock GL, et al. Islet transplantation in seven patients with type 1 diabetes mellitus using a glucocorticoid-free immunosuppressive regimen. N Engl J Med. 2000;343(4):230-8.

5. Lablanche S, Vantyghem MC, Kessler L, Wojtusciszyn A, Borot $\mathrm{S}$, Thivolet $\mathrm{C}$, et al. Islet transplantation versus insulin therapy in patients with type 1 diabetes with severe hypoglycaemia or poorly controlled glycaemia after kidney transplantation (TRIMECO): a multicentre, randomised controlled trial. Lancet Diabetes Endocrinol. 2018;6(7):527-37.

6. Ryan EA, Paty BW, Senior PA, Bigam D, Alfadhli E, Kneteman NM, et al. Five-year follow-up after clinical islet transplantation. Diabetes. 2005;54(7):2060-9.

7. Chhabra P, Sutherland DER, Brayman KL. Overcoming barriers in clinical islet transplantation: current limitations and future prospects. Curr Probl Surg. 2014;51(2):49-86.

8. Bourgeois $\mathrm{S}$, et al. Towards a functional cure for diabetes using stem cell-derived beta cells: are we there yet? Cells. 2021;10:1.

9. Emamaullee JA, Shapiro AMJ. Factors influencing the loss of beta-cell mass in islet transplantation. Cell Transplant. 2007;16(1):1-8.

10. Negi S, Park SH, Jetha A, Aikin R, Tremblay M, Paraskevas S. Evidence of endoplasmic reticulum stress mediating cell death in transplanted human islets. Cell Transplant. 2012;21(5):889-900.

11. Giuliani M, Moritz W, Bodmer E, Dindo D, Kugelmeier P, Lehmann R, et al. Central necrosis in isolated hypoxic human pancreatic islets: evidence for postisolation ischemia. Cell Transplant. 2005;14(1):67-76.

12. Datta P, Ayan B, Ozbolat IT. Bioprinting for vascular and vascularized tissue biofabrication. Acta Biomater. 2017;51:1-20.

13. Pagliuca FW, Millman JR, Gürtler M, Segel M, van Dervort A, Ryu JH, et al. Generation of functional human pancreatic beta cells in vitro. Cell. 2014;159(2):428-39.

14. Helman A, Melton DA. A stem cell approach to cure type 1 diabetes. Cold Spring Harb Perspect Biol. 2021;13:1.

15. Lanzoni G, Ricordi C. Transplantation of stem cell-derived pancreatic islet cells. Nat Rev Endocrinol. 2021;17(1):7-8.

16. Shi Y, Inoue H, Wu JC, Yamanaka S. Induced pluripotent stem cell technology: a decade of progress. Nat Rev Drug Discov. 2017;16(2):115-30.

17. Okita K, Ichisaka T, Yamanaka S. Generation of germlinecompetent induced pluripotent stem cells. Nature. 2007;448(7151):313-U1.

18. Rosado-Olivieri EA, Anderson K, Kenty JH, Melton DA. YAP inhibition enhances the differentiation of functional stem cellderived insulin-producing beta cells. Nat Commun. 2019;10: 1464.

19. Velazco-Cruz L, Song J, Maxwell KG, Goedegebuure MM, Augsornworawat P, Hogrebe NJ, et al. Acquisition of dynamic function in human stem cell-derived beta cells. Stem Cell Reports. 2019;12(2):351-65.

20. Hogrebe NJ, et al. Targeting the cytoskeleton to direct pancreatic differentiation of human pluripotent stem cells. Nat Biotechnol. 2020;38(4):460.

21. Vethe H, Bjørlykke Y, Ghila LM, Paulo JA, Scholz H, Gygi SP, et al. Probing the missing mature beta-cell proteomic landscape in differentiating patient iPSC-derived cells. Sci Rep. 2017;7:4780.

22. Millman JR, et al. Generation of stem cell-derived beta-cells from patients with type 1 diabetes. Nat Commun. 2016;7:11463.

23. Millman JR, Pagliuca FW. Autologous pluripotent stem cellderived-like cells for diabetes cellular therapy. Diabetes. 2017;66(5):1111-20.

24. Zhou Q, Brown J, Kanarek A, Rajagopal J, Melton DA. In vivo reprogramming of adult pancreatic exocrine cells to beta-cells. Nature. 2008;455(7213):627-U30.

25. $\mathrm{Li} \mathrm{WD}$, et al. In vivo reprogramming of pancreatic acinar cells to three islet endocrine subtypes. Elife. 2014;3.

26. Collombat P, Xu X, Ravassard P, Sosa-Pineda B, Dussaud S, Billestrup N, et al. The ectopic expression of Pax4 in the mouse pancreas converts progenitor cells into alpha and subsequently beta cells. Cell. 2009;138(3):449-62.

27. Kim HS, Lee MK. Beta-cell regeneration through the transdifferentiation of pancreatic cells: pancreatic progenitor cells in the pancreas. Journal of Diabetes Investigation. 2016;7(3): 286-96.

28. Grapin-Botton A. Three-dimensional pancreas organogenesis models. Diabetes Obes Metab. 2016;18:33-40.

29. Yoshihara E, O'Connor C, Gasser E, Wei Z, Oh TG, Tseng TW, et al. Immune-evasive human islet-like organoids ameliorate diabetes. Nature. 2021;586:606.

30. Gonzalez BJ, et al. How safe are universal pluripotent stem cells? Cell Stem Cell. 2020;26(3):307-8.

31. Harding J, Vintersten-Nagy K, Nagy A. Universal stem cells: making the unsafe safe. Cell Stem Cell. 2020;27(2):198-9.

32. Deinsberger J, Reisinger D, Weber B. Global trends in clinical trials involving pluripotent stem cells: a systematic multidatabase analysis. Npj Regenerative Medicine. 2020;5:1.

33. Veres A, et al. Charting cellular identity during human in vitro beta-cell differentiation. Nature. 2019;569(7756):368 The study identified CD9 as negative cell-surface marker and CD49a as positive cell-surface marker for purification of IPCs post differentiation procedure.

34. Sneddon JB, Tang Q, Stock P, Bluestone JA, Roy S, Desai T, et al. Stem cell therapies for treating diabetes: progress and remaining challenges. Cell Stem Cell. 2018;22(6):810-23.

35. Liang Q, et al. Linking a cell-division gene and a suicide gene to define and improve cell therapy safety. Nature. 2018;563(7733): 701.

36. Tang SC, Jessup CF, Campbell-Thompson M, The role of accessory cells in islet homeostasis. Current Diabetes Reports. 2018: 18(11).

37. Dominici M, le Blanc K, Mueller I, Slaper-Cortenbach I, Marini FC, Krause DS, et al. Minimal criteria for defining multipotent mesenchymal stromal cells. The International Society for Cellular Therapy position statement. Cytotherapy. 2006;8(4): 315-7.

38. Hass R, Kasper C, Böhm S, Jacobs R. Different populations and sources of human mesenchymal stem cells (MSC): a comparison of adult and neonatal tissue-derived MSC. Cell Communication and Signaling. 2011;9.

39. $\mathrm{Li} \mathrm{XH}$, et al. Change in viability and function of pancreatic islets after coculture with mesenchymal stromal cells: a systemic review and meta-analysis. J Diabetes Res. 2020;2020:1-12.

40. Arzouni AA, Vargas-Seymour A, Dhadda PK, Rackham CL, Huang GC, Choudhary P, et al. Characterization of the effects of 
mesenchymal stromal cells on mouse and human islet function. Stem Cells Transl Med. 2019;8(9):935-44.

41. Gamble A, et al. Improved islet recovery and efficacy through coculture and co-transplantation of islets with human adiposederived mesenchymal stem cells. PLoS One. 2018;13:11.

42. Schive SW, Mirlashari MR, Hasvold G, Wang M, Josefsen D, Gullestad HP, et al. Human adipose-derived mesenchymal stem cells respond to short-term hypoxia by secreting factors beneficial for human islets in vitro and potentiate antidiabetic effect in vivo. Cell Medicine. 2017;9(3):103-16.

43. Ishida N, Ishiyama K, Saeki Y, Tanaka Y, Ohdan H. Cotransplantation of preactivated mesenchymal stem cells improves intraportal engraftment of islets by inhibiting liver natural killer cells in mice. Am J Transplant. 2019;19(10):2732-45.

44. Xv JB, et al. Mesenchymal stem cells moderate immune response of type 1 diabetes. Cell Tissue Res. 2017;368(2):239-48.

45. Hayward JA, Ellis CE, Seeberger K, Lee T, Salama B, MuletSierra A, et al. Cotransplantation of mesenchymal stem cells with neonatal porcine islets improve graft function in diabetic mice. Diabetes. 2017;66(5):1312-21.

46. Rackham CL, Dhadda PK, Chagastelles PC, Simpson SJS, Dattani AA, Bowe JE, et al. Pre-culturing islets with mesenchymal stromal cells using a direct contact configuration is beneficial for transplantation outcome in diabetic mice. Cytotherapy. 2013;15(4):449-59.

47. Lai Y, Schneider D, Kidszun A, Hauck-Schmalenberger I, Breier $\mathrm{G}$, Brandhorst D, et al. Vascular endothelial growth factor increases functional beta-cell mass by improvement of angiogenesis of isolated human and murine pancreatic islets. Transplantation. 2005;79(11):1530-6.

48. Jung EJ, Kim SC, Wee YM, Kim YH, Choi MY, Jeong SH, et al. Bone marrow-derived mesenchymal stromal cells support rat pancreatic islet survival and insulin secretory function in vitro. Cytotherapy. 2011;13(1):19-29.

49. Strioga M, Viswanathan S, Darinskas A, Slaby O, Michalek J. Same or not the same? Comparison of adipose tissue-derived versus bone marrow-derived mesenchymal stem and stromal cells. Stem Cells Dev. 2012;21(14):2724-52.

50. Noel D, et al. Cell specific differences between human adiposederived and mesenchymal-stromal cells despite similar differentiation potentials. Exp Cell Res. 2008;314(7):1575-84.

51. De Ugarte DA, et al. Comparison of multi-lineage cells from human adipose tissue and bone marrow. Cells Tissues Organs. 2003;174(3):101-9.

52. Ohmura Y, Tanemura M, Kawaguchi N, Machida T, Tanida T, Deguchi $\mathrm{T}$, et al. Combined transplantation of pancreatic islets and adipose tissue-derived stem cells enhances the survival and insulin function of islet grafts in diabetic mice. Transplantation. 2010;90(12):1366-73.

53. Vaithilingam V, et al. Co-encapsulation and co-transplantation of mesenchymal stem cells reduces pericapsular fibrosis and improves encapsulated islet survival and function when allografted. Sci Rep. 2017;7.

54. Kogawa R, Nakamura K, Mochizuki Y. A new islet transplantation method combining mesenchymal stem cells with recombinant peptide pieces, microencapsulated islets, and mesh bags. Biomedicines. 2020;8:9.

55. Laporte C, Tubbs E, Pierron M, Gallego A, Moisan A, Lamarche $\mathrm{F}$, et al. Improved human islets' viability and functionality with mesenchymal stem cells and arg-gly-asp tripeptides supplementation of alginate micro-encapsulated islets in vitro. Biochem Biophys Res Commun. 2020;528(4):650-7.

56. Laporte C, Tubbs E, Cristante J, Gauchez AS, Pesenti S, Lamarche F, et al. Human mesenchymal stem cells improve rat islet functionality under cytokine stress with combined upregulation of heme oxygenase-1 and ferritin. Stem Cell Res Ther. 2019;10:85.

57. Montanari E, Meier RPH, Mahou R, Seebach JD, Wandrey C, Gerber-Lemaire $\mathrm{S}$, et al. Multipotent mesenchymal stromal cells enhance insulin secretion from human islets via $\mathrm{N}$-cadherin interaction and prolong function of transplanted encapsulated islets in mice. Stem Cell Res Ther. 2017;8:199.

58. Kerby A, Jones ES, Jones PM, King AJ. Co-transplantation of islets with mesenchymal stem cells in microcapsules demonstrates graft outcome can be improved in an isolated-graft model of islet transplantation in mice. Cytotherapy. 2013;15(2):192-200.

59. Bhang SH, Jung MJ, Shin JY, la WG, Hwang YH, Kim MJ, et al. Mutual effect of subcutaneously transplanted human adiposederived stem cells and pancreatic islets within fibrin gel. Biomaterials. 2013;34(30):7247-56.

60. Xue L, Greisler HP. Angiogenic effect of fibroblast growth factor1 and vascular endothelial growth factor and their synergism in a novel in vitro quantitative fibrin-based 3-dimensional angiogenesis system. Surgery. 2002;132(2):259-67.

61. Dai XZ, Cai SX, Ye QF, Jiang JH, Yan XQ, Xiong X, et al. A novel in vitro angiogenesis model based on a microfluidic device. Chin Sci Bull. 2011;56(31):3301-9.

62. Paraskevas S, Maysinger D, Wang R, Duguid WP, Rosenberg L. Cell loss in isolated human islets occurs by apoptosis. Pancreas. 2000;20(3):270-6.

63. Koike N, Fukumura D, Gralla O, Au P, Schechner JS, Jain RK. Creation of long-lasting blood vessels. Nature. 2004;428(6979): $138-9$.

64. Lesman A, Habib M, Caspi O, Gepstein A, Arbel G, Levenberg S, et al. Transplantation of a tissue-engineered human vascularized cardiac muscle. Tissue Eng A. 2010;16(1):115-25.

65. Gupta R, Sefton MV. Application of an endothelialized modular construct for islet transplantation in syngeneic and allogeneic immunosuppressed rat models. Tissue Eng A. 2011;17(15-16): 2005-15.

66. Menger MD, Jaeger S, Walter P, Feifel G, Hammersen F, Messmer K. Angiogenesis and hemodynamics of microvasculature of transplanted islets of Langerhans. Diabetes. 1989;38:199 201.

67. Boettler T, et al. Pancreatic tissue transplanted in TheraCyte (TM) encapsulation devices is protected and prevents hyperglycemia in a mouse model of immune-mediated diabetes. Cell Transplant. 2016;25(3):609-14 Pre-vascularization of macroencapsulation device, TheraCyte, in the subcutaneous site of the diabetic mice 3 months prior to implantation of islets accelerated diabetes treatment.

68. Bowers DT, Song W, Wang LH, Ma M. Engineering the vasculature for islet transplantation. Acta Biomater. 2019;95:131-51.

69. Bank RA. Limiting biomaterial fibrosis. Nat Mater. 2019;18(8): 781.

70. Witherel CE, et al. Macrophage and fibroblast interactions in biomaterial-mediated fibrosis. Advanced Healthcare Materials. 2019:8(4).

71.• Pepper AR, et al. A prevascularized subcutaneous device-less site for islet and cellular transplantation. Nat Biotechnol. 2015;33(5): $518-\mathrm{U} 233$ The study presents a device-less approach in which a nylon catheter was used to create a pre-vascularized pocket for pancreatic islets 1 month prior to islet transplantation in the subcutaneous site of diabetic mice model. The catheter was removed prior islet. The animals maintained normoglycemic over 100 days post islet implantation and no sign of fibrosis was observed.

72. Hajizadeh-Saffar E, Tahamtani Y, Aghdami N, Azadmanesh K, Habibi-Anbouhi M, Heremans Y, et al. Inducible VEGF expression by human embryonic stem cell-derived mesenchymal stromal 
cells reduces the minimal islet mass required to reverse diabetes. Sci Rep. 2015;5.

73. Perez-Basterrechea M, Briones RM, Alvarez-Viejo M, GarciaPerez E, Esteban MM, Garcia V, et al. Plasma-fibroblast gel as scaffold for islet transplantation. Tissue Eng A. 2009;15(3):569 77.

74. Takahashi Y, Sekine K, Kin T, Takebe T, Taniguchi H. Selfcondensation culture enables vascularization of tissue fragments for efficient therapeutic transplantation. Cell Rep. 2018;23(6): $1620-9$.

75. Lebreton, F., et al., Insulin-producing organoids engineered from islet and amniotic epithelial cells to treat diabetes. Nature Communications 2019. 10. Generation of mini-organoids with pancreatic islets combined with HUVECs and MSCs in order to increase the vascularization as well as survival and function of the islets.

76. Apte MV, Pirola RC, Wilson JS. Pancreatic stellate cells: a starring role in normal and diseased pancreas. Front Physiol. 2012;3.

77. Zha M, et al. Isolation and characterization of islet stellate cells in rat. Islets. 2014;6:2.

78. Zha M, Xu W, Jones PM, Sun Z. Isolation and characterization of human islet stellate cells. Exp Cell Res. 2016;341(1):61-6.

79. Nielsen MFB, Mortensen MB, Detlefsen S. Identification of markers for quiescent pancreatic stellate cells in the normal human pancreas. Histochem Cell Biol. 2017;148(4):359-80.

80. Lardon J, Rooman I, Bouwens L. Nestin expression in pancreatic stellate cells and angiogenic endothelial cells. Histochem Cell Biol. 2002;117(6):535-40.

81. Phillips PA, McCarroll J, Park S, Wu MJ, Pirola R, Korsten M, et al. Rat pancreatic stellate cells secrete matrix metal loproteinases: implications for extracellular matrix turnover. Gut. 2003;52(2):275-82.

82. Masamune A, Kikuta K, Watanabe T, Satoh K, Satoh A, Shimosegawa T. Pancreatic stellate cells express Toll-like receptors. J Gastroenterol. 2008;43(5):352-62.

83. Fujita T, Narumiya S. Roles of hepatic stellate cells in liver inflammation: a new perspective. Inflammation and Regeneration. 2016;36:1

84. Chen CH, Kuo LM, Chang Y, Wu W, Goldbach C, Ross MA, et al. In vivo immune modulatory activity of hepatic stellate cells in mice. Hepatology. 2006;44(5):1171-81.

85. Bynigeri RR, Jakkampudi A, Jangala R, Subramanyam C, Sasikala M, Rao GV, et al. Pancreatic stellate cell: Pandora's box for pancreatic disease biology. World J Gastroenterol. 2017;23(3):382-405.

86. Zang GX, et al. Activated pancreatic stellate cells can impair pancreatic islet function in mice. Ups J Med Sci. 2015;120(3):169-80.

87. Lee E, Ryu GR, Ko SH, Ahn YB, Song KH. A role of pancreatic stellate cells in islet fibrosis and beta-cell dysfunction in type 2 diabetes mellitus. Biochem Biophys Res Commun. 2017;485(2): 328-34.

88. Li FF, Chen BJ, Li W, Li L, Zha M, Zhou S, et al. Islet stellate cells isolated from fibrotic islet of Goto-Kakizaki rats affect biological behavior of beta-cell. J Diabetes Res. 2016;2016:1-9.

89. Donath MY, Böni-Schnetzler M, Ellingsgaard H, Ehses JA. Islet inflammation impairs the pancreatic beta-cell in type 2 diabetes. Physiology. 2009;24(6):325-31.

90. Xue J, Sharma V, Hsieh MH, Chawla A, Murali R, Pandol SJ, et al. Alternatively activated macrophages promote pancreatic fibrosis in chronic pancreatitis. Nat Commun. 2015;6:7158.

91. Dimitrioglou N, Kanelli M, Papageorgiou E, Karatzas T, Hatziavramidis D. Paving the way for successful islet encapsulation. Drug Discov Today. 2019;24(3):737-48.

92. Yang HK, Yoon KH. Current status of encapsulated islet transplantation. J Diabetes Complicat. 2015;29(5):737-43.
93. Kim J, Shim IK, Hwang DG, Lee YN, Kim M, Kim H, et al. 3D cell printing of islet-laden pancreatic tissue-derived extracellular matrix bioink constructs for enhancing pancreatic functions. J Mater Chem B. 2019;7(10):1773-81.

94. Zhi ZL, Khan F, Pickup JC. Multilayer nanoencapsulation: a nanomedicine technology for diabetes research and management. Diabetes Res Clin Pract. 2013;100(2):162-9.

95. Kozlovskaya V, Zavgorodnya O, Chen Y, Ellis K, Tse HM, Cui $\mathrm{W}$, et al. Ultrathin polymeric coatings based on hydrogen-bonded polyphenol for protection of pancreatic islet cells. Adv Funct Mater. 2012;22(16):3389-98.

96. Motte E, et al. Composition and function of macroencapsulated human embryonic stem cell-derived implants: comparison with clinical human islet cell grafts. American Journal of PhysiologyEndocrinology and Metabolism. 2014;307(9):E838-46.

97. Dufrane D, Goebbels RM, Gianello P. Alginate macroencapsulation of pig islets allows correction of streptozotocin-induced diabetes in primates up to 6 months without immunosuppression. Transplantation. 2010;90(10):1054-62.

98. Ludwig B, Rotem A, Schmid J, Weir GC, Colton CK, Brendel $\mathrm{MD}$, et al. Improvement of islet function in a bioartificial pancreas by enhanced oxygen supply and growth hormone releasing hormone agonist. Proc Natl Acad Sci U S A. 2012;109(13):5022-7.

99. Hu SX, et al. Toll-like receptor 2-modulating pectin-polymers in alginate-based microcapsules attenuate immune responses and support islet-xenograft survival. Biomaterials. 2021;266:120460.

100. Duvivier-Kali VF, Omer A, Lopez-Avalos MD, O'Neil JJ, Weir GC. Survival of microencapsulated adult pig islets in mice in spite of an antibody response. Am J Transplant. 2004;4(12):19912000 .

101. Safley SA, Kenyon NS, Berman DM, Barber GF, Cui H, Duncanson S, et al. Microencapsulated islet allografts in diabetic NOD mice and nonhuman primates. Eur Rev Med Pharmacol Sci. 2020;24(16):8551-65.

102.• Safley SA, et al. Microencapsulated adult porcine islets transplanted intraperitoneally in streptozotocin-diabetic non-human primates. Xenotransplantation. 2018;25:6 First clinical trial for implanting human ESCs-derived pancreatic progenitor cells in a macroencapsulation device. The device was safe and protected the cells from the host immune system, although it did not promote vascularization, which leaded to poor insulin-producing cell function post-implantation.

103. Weaver JD, Headen DM, Hunckler MD, Coronel MM, Stabler CL, García AJ. Design of a vascularized synthetic poly(ethylene glycol) macroencapsulation device for islet transplantation. Biomaterials. 2018;172:54-65.

104. Ernst AU, Wang LH, Ma ML. Interconnected toroidal hydrogels for islet encapsulation. Advanced Healthcare Materials. 2019;8: 12.

105. Lee SH, Park HS, Yang Y, Lee EY, Kim JW, Khang G, et al. Improvement of islet function and survival by integration of perfluorodecalin into microcapsules in vivo and in vitro. $\mathrm{J}$ Tissue Eng Regen Med. 2018;12(4):E2110-22.

106. Kuwabara R, Iwata H. Bioabsorbable device to prepare subcutaneous pockets for islet transplantation. Journal of Biomedical Materials Research Part B-Applied Biomaterials. 2019;107(4): 1107-12.

107. Mao D, Zhu M, Zhang X, Ma R, Yang X, Ke T, et al. A macroporous heparin-releasing silk fibroin scaffold improves islet transplantation outcome by promoting islet revascularisation and survival. Acta Biomater. 2017;59:210-20.

108. Gebe JA, Preisinger A, Gooden MD, D'Amico LA, Vernon RB. Local, controlled release in vivo of vascular endothelial growth factor within a subcutaneous scaffolded islet implant reduces early islet necrosis and improves performance of the graft. Cell Transplant. 2018;27(3):531-41. 
109. Borg DJ, Welzel PB, Grimmer M, Friedrichs J, Weigelt M, Wilhelm C, et al. Macroporous biohybrid cryogels for cohousing pancreatic islets with mesenchymal stromal cells. Acta Biomater. 2016;44:178-87.

110. Yang B, Cao G, Cai K, Wang G, Li P, Zheng L, et al. VEGFmodified PVA/silicone nanofibers enhance islet function transplanted in subcutaneous site followed by device-less procedure. Int J Nanomedicine. 2020;15:587-99.

111. Farina M, et al. 3D printed vascularized device for subcutaneous transplantation of human islets. Biotechnol J. 2017;12:9.

112. Liu X, et al. Development of a coaxial 3D printing platform for biofabrication of implantable islet-containing constructs. Advanced Healthcare Materials. 2019;8:7.

113. Hill RS, et al. Immunoisolation of adult porcine islets for the treatment of diabetes mellitus - the use of photopolymerizable polyethylene glycol in the conformal coating of mass-isolated porcine islets. Bioartificial Organs. 1997;831:332-43.

114. Park H, Haque MR, Park JB, Lee KW, Lee S, Kwon Y, et al. Polymeric nano-shielded islets with heparin-polyethylene glycol in a non-human primate model. Biomaterials. 2018;171:164-77.

115. Hwa AJ, Weir GC. Transplantation of macroencapsulated insulinproducing cells. Current Diabetes Reports. 2018;18:8.

116. Ludwig B, Reichel A, Steffen A, Zimerman B, Schally AV, Block NL, et al. Transplantation of human islets without immunosuppression. Proc Natl Acad Sci U S A. 2013;110(47):19054-8.

117.• Yoshihara E, et al. Immune-evasive human islet-like organoids ameliorate diabetes. Nature. 2020;586(7830):606 First study that reported the printability of pancreatic islets and insulinproducing beta cells mixed with hydrogel in direct extrusionbased bioprinting.

118. van der Torren CR, Zaldumbide A, Duinkerken G, Brand-Schaaf SH, Peakman M, Stangé G, et al. Immunogenicity of human embryonic stem cell-derived beta cells. Diabetologia. 2017;60(1): 126-33.

119. Schulz TC. Concise Review: manufacturing of pancreatic endoderm cells for clinical trials in type 1 diabetes. Stem Cells Transl Med. 2015;4(8):927-31.

120. Henry RR, et al. Initial clinical evaluation of VC-01TM combination product - a stem cell-derived islet replacement for type 1 diabetes (T1D). Diabetes. 2018;67.

121. Carlsson PO, Espes D, Sedigh A, Rotem A, Zimerman B, Grinberg H, et al. Transplantation of macroencapsulated human islets within the bioartificial pancreas air to patients with type 1 diabetes mellitus. Am J Transplant. 2018;18(7):1735-44.

122. Soonshiong $\mathrm{P}$, et al. Insulin independence in a type-1 diabetic patient after encapsulated islet transplantation. Lancet. 1994;343(8903):950-1.

123. Calafiore R, Basta G, Luca G, Lemmi A, Montanucci MP, Calabrese G, et al. Microencapsulated pancreatic islet allografts into nonimmunosuppressed patients with type 1 diabetes - first two cases. Diabetes Care. 2006;29(1):137-8.

124. Basta G, Montanucci P, Luca G, Boselli C, Noya G, Barbaro B, et al. Long-term metabolic and immunological follow-up of nonimmunosuppressed patients with type 1 diabetes treated with microencapsulated islet allografts. Diabetes Care. 2011;34(11): 2406-9.

125. Matsumoto S, Abalovich A, Wechsler C, Wynyard S, Elliott RB. Clinical benefit of islet xenotransplantation for the treatment of type 1 diabetes. Ebiomedicine. 2016;12:255-62.

126. Krol S, Baronti W, Marchetti P. Nanoencapsulated human pancreatic islets for beta-cell replacement in type 1 diabetes. Nanomedicine. 2020;15(18):1735-8.

127. An D, Chiu A, Flanders JA, Song W, Shou D, Lu YC, et al. Designing a retrievable and scalable cell encapsulation device for potential treatment of type 1 diabetes. Proc Natl Acad Sci U S A. 2018;115(2):E263-72.
128. Omer A, Duvivier-Kali VF, Aschenbach W, Tchipashvili V, Goodyear LJ, Weir GC. Exercise induces hypoglycemia in rats with islet transplantation. Diabetes. 2004;53(2):360-5.

129. Trivedi N, Keegan M, Steil GM, Hollister-Lock J, Hasenkamp WM, Colton CK, et al. Islets in alginate macrobeads reverse diabetes despite minimal acute insulin secretory responses. Transplantation. 2001;71(2):203-11.

130. Weaver JD, et al. Vasculogenic hydrogel enhances islet survival, engraftment, and function in leading extrahepatic sites. Sci Adv. 2017:3(6).

131. Lee KY, Mooney DJ. Alginate: properties and biomedical applications. Prog Polym Sci. 2012;37(1):106-26.

132. Nyitray CE, Chang R, Faleo G, Lance KD, Bernards DA, Tang Q, et al. Polycaprolactone thin-film micro- and nanoporous cellencapsulation devices. ACS Nano. 2015;9(6):5675-82.

133. Espona-Noguera A, Etxebarria-Elezgarai J, Saenz del Burgo L, Cañibano-Hernández A, Gurruchaga H, Blanco FJ, et al. Type 1 diabetes mellitus reversal via implantation of magnetically purified microencapsulated pseudoislets. Int J Pharm. 2019;560:6577.

134.• Zorzi D, Phan T, Sequi M, Lin Y, Freeman DH, Cicalese L, et al. Impact of islet size on pancreatic islet transplantation and potential interventions to improve outcome. Cell Transplant. 2015;24(1): 11-23 Promising data for subcutaneous implantation site. The study reports the implantation of islets in type I collagen-based scaffold in the subcutaneous site of immunocompromised mice and immunocompetent mice with administration of immunosuppressive regimen. Islets in both models reversed diabetes and showed improved angiogenesis post implantation.

135. Tomei AA, Manzoli V, Fraker CA, Giraldo J, Velluto D, Najjar $\mathrm{M}$, et al. Device design and materials optimization of conformal coating for islets of Langerhans. Proc Natl Acad Sci U S A. 2014;111(29):10514-9.

136. Skrzypek K, Groot Nibbelink M, van Lente J, Buitinga M, Engelse MA, de Koning EJP, et al. Pancreatic islet macroencapsulation using microwell porous membranes. Sci Rep. 2017;7:9186.

137. Wilson JT, Cui WX, Chaikof EL. Layer-by-layer assembly of a conformal nanothin PEG coating for intraportal islet transplantation. Nano Lett. 2008;8(7):1940-8.

138. Phelps EA, et al. Maleimide cross-linked bioactive PEG hydrogel exhibits improved reaction kinetics and cross-linking for cell encapsulation and in situ delivery. Adv Mater. 2012;24(1):64.

139. Hwang PTJ, Shah DK, Garcia JA, Bae CY, Lim DJ, Huiszoon $\mathrm{RC}$, et al. Progress and challenges of the bioartificial pancreas. Nano Convergence. 2016;3:28.

140. Gurlin, R.E., J.A. Giraldo, and E. Latres, 3D bioprinting and translation of beta cell replacement therapies for type 1 diabetes. Tissue Engineering Part B-Reviews, 2020.

141. Marchioli, G., et al., Fabrication of three-dimensional bioplotted hydrogel scaffolds for islets of Langerhans transplantation. Biofabrication 2015. 72

142. Duin S, et al. 3D bioprinting of functional islets of langerhans in an alginate/methylcellulose hydrogel blend. Advanced Healthcare Materials. 2019:8(7) Generation of biological islet scaffold by mixing the islets with the plasma of the recipient. Adding thrombin to the scaffold at the site of transplantation in the omentum converts fibrinogen to fibrin and polymerizes the scaffold.

143. Nam SY, Park SH. ECM based bioink for tissue mimetic 3D bioprinting. Biomimetic Medical Materials: From Nanotechnology to 3d Bioprinting. 2018;1064:335-53.

144. Suntornnond R, Tan EYS, An J, Chua CK. A highly printable and biocompatible hydrogel composite for direct printing of soft and perfusable vasculature-like structures. Sci Rep. 2017;7:16902. 
145. Hinton TJ, et al. Three-dimensional printing of complex biological structures by freeform reversible embedding of suspended hydrogels. Sci Adv. 2015:1(9).

146. Scholz H, SA Y, Zhao DJ, Gullestad HP, Thompson E, Troedsson $\mathrm{C}$, et al. 3D bioprinting of biomimetic pancreas with biocompatible hydrogel, adiposederived stem cells and islets. TERMIS. 2019.

147. Marchioli G, Luca AD, de Koning E, Engelse M, van Blitterswijk CA, Karperien M, et al. Hybrid polycaprolactone/alginate scaffolds functionalized with VEGF to promote de novo vessel formation for the transplantation of islets of Langerhans. Advanced Healthcare Materials. 2016;5(13):1606-16.

148. Perez-Basterrechea M, Esteban MM, Vega JA, Obaya AJ. Tissueengineering approaches in pancreatic islet transplantation. Biotechnol Bioeng. 2018;115(12):3009-29.

149. Christoffersson G, Henriksnäs J, Johansson L, Rolny C, Ahlström $\mathrm{H}$, Caballero-Corbalan J, et al. Clinical and experimental pancreatic islet transplantation to striated muscle establishment of a vascular system similar to that in native islets. Diabetes. 2010;59(10): 2569-78.

150. Bertuzzi F, Colussi G, Lauterio A, de Carlis L. Intramuscular islet allotransplantation in type 1 diabetes mellitus. Eur Rev Med Pharmacol Sci. 2018;22(6):1731-6.

151. Tsuchiya $\mathrm{H}$, et al. Extracellular matrix and growth factors improve the efficacy of intramuscular islet transplantation. PLoS One. 2015;10:10.

152. Witkowski P, Sondermeijer H, Hardy MA, Woodland DC, Lee K, Bhagat $\mathrm{G}$, et al. Islet grafting and imaging in a bioengineered intramuscular space. Transplantation. 2009;88(9):1065-74.

153. Saito T, Ohashi K, Utoh R, Shimizu H, Ise K, Suzuki H, et al. Reversal of diabetes by the creation of neo-islet tissues into a subcutaneous site using islet cell sheets. Transplantation. 2011;92(11):1231-6.

154. Yasunami Y, Nakafusa Y, Nitta N, Nakamura M, Goto M, Ono J, et al. A novel subcutaneous site of islet transplantation superior to the liver. Transplantation. 2018;102(6):945-52.

155. Xu K, Xie R, Lin X, Jia J, Zeng N, Li W, et al. Brown adipose tissue: a potential site for islet transplantation. Transplantation. 2020;104(10):2059-64.

156. Hadavi E, Leijten J, Brinkmann J, Jonkheijm P, Karperien M, van Apeldoorn A. Fibronectin and collagen IV microcontact printing improves insulin secretion by INS1E cells. Tissue Engineering Part C-Methods. 2018;24(11):628-36.

157. $\mathrm{Yu} \mathrm{M}$, et al. Islet transplantation in the subcutaneous space achieves long-term euglycaemia in preclinical models of type 1 diabetes. Nat Metab. 2020;2(10):1013-20.

158. Rajab A. Islet transplantation: alternative sites. Current Diabetes Reports. 2010;10(5):332-7.

159. Kawakami Y, Iwata H, Gu Y, Miyamoto M, Murakami Y, Yamasaki T, et al. Modified subcutaneous tissue with neovascularization is useful as the site for pancreatic islet transplantation. Cell Transplant. 2000;9(5):729-32.
160. Wang ZM, et al. Novel biomaterial strategies for controlled growth factor delivery for biomedical applications. Npg Asia Materials. 2017;9:e435.

161. Yasunami Y, Lacy PE, Finke EH. A new site for islet transplantation - a peritoneal-omental pouch. Transplantation. 1983;36(2):181-2.

162. Chaffanjon PCJ, Kenyon NM, Ricordi C, Kenyon NS. Omental anatomy of non-human primates. Surg Radiol Anat. 2005;27(4): 287-91.

163. Berman DM, O'Neil JJ, Coffey LC, Chaffanjon PC, Kenyon NM, Ruiz P Jr, et al. Long-term survival of nonhuman primate islets implanted in an omental pouch on a biodegradable scaffold. Am J Transplant. 2009;9(1):91-104.

164. Kriz J, Vilk G, Mazzuca DM, Toleikis PM, Foster PJ, White DJG. A novel technique for the transplantation of pancreatic islets within a vascularized device into the greater omentum to achieve insulin independence. Am J Surg. 2012;203(6):793-7.

165. Berman DM, et al. Bioengineering the endocrine pancreas: intraomental islet transplantation within a biologic resorbable scaffold. Diabetes. 2016;65(5):1350-61.

166. Bru-Tari E, D.O.a.P.L.H. Cell heterogeneity and paracrine interactions in human islet function: a perspective focused in $\beta$-cell regeneration strategies. Front Endocrinol. 2021:11.

167. Jain R, Lammert E. Cell-cell interactions in the endocrine pancreas. Diabetes Obes Metab. 2009;11:159-67.

168. Kropp C, Massai D, Zweigerdt R. Progress and challenges in large-scale expansion of human pluripotent stem cells. Process Biochem. 2017;59:244-54.

169. Krawetz R, Taiani JT, Liu S, Meng G, Li X, Kallos MS, et al. Large-scale expansion of pluripotent human embryonic stem cells in stirred-suspension bioreactors. Tissue Engineering Part CMethods. 2010;16(4):573-82.

170. Halldorsson S, Lucumi E, Gómez-Sjöberg R, Fleming RMT. Advantages and challenges of microfluidic cell culture in polydimethylsiloxane devices. Biosens Bioelectron. 2015;63:218-31.

171. Regehr KJ, Domenech M, Koepsel JT, Carver KC, Ellison-Zelski SJ, Murphy WL, et al. Biological implications of polydimethylsiloxane-based microfluidic cell culture. Lab Chip. 2009;9(15):2132-9.

172. van Meer BJ, de Vries H, Firth KSA, van Weerd J, Tertoolen LGJ, Karperien HBJ, et al. Small molecule absorption by PDMS in the context of drug response bioassays. Biochem Biophys Res Commun. 2017;482(2):323-8.

173. Orive G, Santos E, Poncelet D, Hernández RM, Pedraz JL, Wahlberg LU, et al. Cell encapsulation: technical and clinical advances. Trends Pharmacol Sci. 2015;36(8):537-46.

174. Pawar SN, Edgar KJ. Alginate derivatization: a review of chemistry, properties and applications. Biomaterials. 2012;33(11): 3279-305.

Publisher's Note Springer Nature remains neutral with regard to jurisdictional claims in published maps and institutional affiliations. 